\title{
Árangur magahjáveituaðgerða á Íslandi 2001-2015
}

\author{
Rósamunda Pórarinsdóttir ${ }^{1} æ k n a n e m i$, Vilhjálmur Pálmason ${ }^{1}$ læknanemi, Björn Geir Leifsson ${ }^{2}$ læknir, \\ Hjörtur Gíslason² læknir
}

\section{ÁGRIP}

Inngangur: Magahjáveituaðgerðir með kviðsjártækni hafa verið framkvæmdar á Landspítala frá árinu 2001. Aðgerðirnar eru mikilvægur meðferðarmöguleiki fyrir sjúklinga með sjúklega offitu. Markmið pessarar rannsóknar var að̃ kanna langtímaárangur slíkra aðgerða hérlendis. Efniviður og aðferðir: Rannsóknin tók til 772 sjúklinga sem gengust undir magahjáveituaðgerð á Landspítala árin 2001-2015. Upplýsinga var aflað úr framskyggnum gagnagrunni offituaðgerða sem er hluti af sjúkraskrárkerfi spítala. Fullnægjandi pyngdartap var skilgreint sem annaðhvort pyngdarstuðull undir $33 \mathrm{~kg} / \mathrm{m}^{2}$ eða meira en helmingstap af yfirpyngd (\%EBMIL skilgreint sem prósenta af tapi á yfirpyngd, umfram pyngdarstuðul $25 \mathrm{~kg} / \mathrm{m}^{2}$ ).

Niðurstöður: Meðalaldur sjúklinga var 41 ár. 83\% voru konur. Meðalpyngd sjúklinga var $127 \mathrm{~kg}( \pm 20)$ og líkamspyngdarstuðull (BMI, $\left.\mathrm{kg} / \mathrm{m}^{2}\right)$ var 44 ( \pm 6$)$ að meðaltali. Meðal \%EBMIL var $80 \%$ eða $57 \mathrm{~kg}( \pm 15)$ eftir 1,5 ár, $70 \%$ eða $50 \mathrm{~kg}( \pm 15)$ eftir 5 ár og $64 \%$ eða $48 \mathrm{~kg}( \pm 14)$ eftir $10-13$ ár.
85\% sjúklinga náđu fullnægjandi pyngdartapi með međaleftirfylgni 7,4 ár eftir aðgerð. Sjúklingar voru að meðaltali með 2,8 fylgisjúkdóma offitu fyrir aðgerð. $71 \%$ sjúklinga með sykursýki af tegund tvö fyrir aðgerð fóru í fullt sjúkdómshlé eftir aðgerð. Rúmlega priðjungur sjúklinga með háprýsting eða blóðfituraskanir urðu lyfjalausir eftir aðgerð. Snemmkomna fylgikvilla fengu 37 (5\%) sjúklingar og fór helmingur peirra í bráđaaðgerð. Síðkomna fylgikvilla eftir aðgerð fékk fjórðungur sjúklinga (174). Hjá flestum sjúklinganna (78\%) purfti að gera endurteknar breytingar á inntöku vítamína og bætiefna í samræmi við niðurstöður blóðprufa í eftirliti.

Ályktun: Magahjáveituađgerð hjálpar meirihluta sjúklinga að ná tilsettu pyngdartapi. Samhliða pví fékk meirihluti sjúklinga bót á fylgisjúkdómum offitu. Snemmkomnir fylgikvillar voru fátíðir en um fjórðungur sjúklinga fékk síðkomna fylgikvilla sem stundum kröfðust nýrrar aðgerðar. Sjúklingar sem fara í magahjáveituađgerð purfa á ævilöngu eftirliti á næringarástandi að halda.

\section{Inngangur}

Vaxandi hlutfall of pungra og of feitra er alvarlegt heilsufarsvandamál um allan heim og hlutfall of feitra hefur tvöfaldast frá árinu 1980. ${ }^{1,2}$ Á Íslandi er nú um fimmtungur fullorðinna of feitur. ${ }^{3}$ Tengsl offitu við aukna tíðni ýmissa sjúkdóma, svo sem sykursýki af tegund tvö (insúlínóháð sykursýki), háprýstings, blóðfituraskana og kæfisvefns eru vel pekkt.,4-7 Fylgisjúkdómar offitu leiða til aukinnar tíðni hjarta- og æðasjúkdóma og krabbameina ásamt minnkuðum lífslíkum. ${ }^{8-10}$ Ýmsar leiðir til megrunar hafa verið reyndar síðustu áratugi hjá sjúklingum með sjúklega offitu, meðal annars mismunandi megrunarkúrar, ýmsar atferlismeðferðir, pjálfunaraðferðir og lyf. Tímabundið pyngdartap næst iðulega og líðan sjúklinga og ástand fylgisjúkdóma offitu batnar til skamms tíma. Rannsóknir hafa hins vegar sýnt að engin pessara aðferða leiðir til varanlegs árangurs hjá sjúklingum með sjúklega offitu. ${ }^{11-16}$ Sýnt hefur verið fram á að offituaðgerðir eru eina meðferðarúrræðið sem stuðlar að langvarandi pyngdartapi, bættu ástandi fylgisjúkdóma og betri lifun sjúklinga með sjúklega offitu. ${ }^{17-20}$

Markmið pessarar rannsóknar var að kanna árangur magahjáveituaðgerða á rannsóknartímabilinu og pá sérstaklega áhrif

Fyrirspurnir: Hjörtur Gíslason, hjorturg@landspitali.is

'Læknadeild Háskóla Íslands, ²skurðsviði Landspítala.

Höfundar hafa útfyllt eyðublað um hagsmunatengsl.

Greinin barst 23. maí 2016, sampykkt til birtingar 19. september 2016. doi.org/10.17992//bl.2016.10.100 aðgerðar á pyngdartap og fylgisjúkdóma offitu. Einnig var tíðni fylgikvilla aðgerðar könnuð.

\section{Efni og aðferðir}

Rannsóknin var framskyggn og tók til 772 sjúklinga sem gengust undir magahjáveituaðgerð með kviðsjártækni á Landspítala á tímabilinu 2001-2015.

Aðgerðarábending fylgdi viðurkenndum evrópskum stöðlum fyrir magahjáveituaðgerðir. ${ }^{21}$ Til pess að uppfylla skilyrði pess að gangast undir aðgerð purftu sjúklingar að vera greindir með sjúklega offitu (BMI $>40 \mathrm{~kg} / \mathrm{m}^{2}$ eða BMI $>35 \mathrm{~kg} / \mathrm{m}^{2}$ ásamt alvarlegum fylgisjúkdómi) (BMI= Body Mass Index, líkamspyngdarstuðull) og hafa mistekist að léttast eða viðhalda pyngdartapi til lengri tíma. Ómeðhöndlaður alvarlegur geðsjúkdómur eða virk áfengis- eða lyfjafíkn töldust frábending aðgerðar. ${ }^{21}$ Alvarlegir fylgikvillar sem kröfðust virkrar meðferðar eða aðgerðar voru skráðir. Ófullnægjandi pyngdartap eftir aðgerð er skilgreint sem BMI yfir 33 eða аð hafa misst minna en $50 \%$ af yfirpyngdinni (BMI $>25) .{ }^{21}$ Skilgreining á fullum bata af sykursýki af tegund tvö er fastandi blóðsykur $<5,6$ mmól/l og langtíma blóðsykur (HbA1c) $<42$ mmól/mól í að minnsta kosti eitt ár án lyfjameðferðar eftir aðgerð. ${ }^{22}$ Fullur bati af háprýstingi er skilgreindur sem blóðprýstingur $<130 / 85$ mmHg, án lyfjameðferðar í eitt ár. Fullur bati af blóðfituröskunum er fastandi HDL $>1,0$ mmól/1 hjá körlum og HDL $>1,3$ mmól/1 hjá konum ásamt tríglýseríð <1,7 mmól/l án lyfjameðferðar.

Áður en aðgerð var ákveðin tóku flestir sjúklinganna pátt í 5-8 vikna pverfaglegri atferlismeðferð á Reykjalundi, ${ }^{23,24}$ Kristnesi 
eða Neskaupsstað. Metin var andleg heilsa og hæfni sjúklings til meðferðarheldni. Sjúklingur purfti að sýna fram á vilja og færni til að framkvæma pær lífsstílsbreytingar sem nauðsynlegar eru ef aðgerðin á að skila varanlegum árangri. Meðferðin fólst í pví að hvetja og styrkja sjúklinga andlega og hjálpa peim að léttast um að minnsta kosti $5 \%$ af upphafspyngd sinni. Einnig var lögð áhersla á að sjúklingur hætti að reykja.

Eftir magahjáveituaðgerðina tók við langtímaeftirfylgni par sem sjúklingar purftu að mæta reglulega í blóðprufur. Sjúklingum var ráðlagt að taka bætiefni til pess að minnka hættu á snefilefna- og vítamínskorti sem er aukin eftir magahjáveituaðgerð. Par er helst um að ræða B12-skort, járnskort hjá konum vegna tíðablæðinga, kalk- og D-vítamínskort. Sjúklingar komu í reglubundið eftirlit á göngudeild megrunaraðgerða Landspítala fyrstu árin. Fyrsta heimsókn var venjulega tveimur vikum eftir aðgerð, síðan eftir prjá mánuði og aftur eftir 9 mánuði. Að pví loknu komu sjúklingar í eftirlit á 6 mánaða fresti. Í hverju eftirliti voru blóðprufur teknar og pyngdin skráð. Pegar sjúklingar höfðu sýnt fram á meðferðarheldni og árangur áttu peir kost á pví að sinna eftirliti sínu með aðstoð heilsugæslu.

\section{Gagnaöflun}

Frá upphafi hefur klínískum upplýsingum um sjúklinga verið safnað í partilgerðan framskyggnan gagnagrunn offituaðgerða sem er hluti af sjúkraskrárkerfi Landspítala. Gagnagrunnurinn er mikilvægt hjálpar- og öryggistæki í daglegu starfi offituteymisins.

Hringt var í alla pá sem gengust undir aðgerðina á rannsóknartímabilinu, peir fengnir til að svara spurningum af stöðluðum spurningalista og svörin skrád í gagnagrunninn. Pessi gögn voru síðan dregin úr gagnagrunninum og unnin tölfræði um afdrif, öryggi og árangur aðgerðar í tölfræðiforritunum SPSS (MacOs, version 22.0) og Microsoft Excel.

Úr staðlaða spurningalistanum fengust upplýsingar um núverandi pyngd sjúklings, fylgikvilla eða aukaverkanir aðgerðar, breytingar á fylgisjúkdómum, nýkomna sjúkdóma og lyfjatöku. Einnig fengust upplýsingar um breytingar á venjum ásamt upplýsingum um atvinnu, líkamsrækt og félagsaðstæður. Að lokum var sjúklingi boðið að koma í blóðprufu og endurkomu á göngudeild. Að auki var upplýsinga aflað úr sjúkraskrám allra peirra sem gengust undir aðgerðina á rannsóknartímabilinu. Áður en gagnaöflun hófst lágu fyrir tilskilin leyfi siðanefndar Landspítala (no. 8/2016) og frá framkvæmdastjóra lækninga á Landspítala.

\section{Aðgerðartæknin}

Aðgerðin er framkvæmd í svæfingu með kviðsjártækni með beinum heftibyssum kenndri við Lönroth ${ }^{25}$ sem er nú algengast að nota í Evrópu. Magi var heftaður sundur strax neðan við vélinda og stærri hluti magans (um 95\%) pannig frátengdur (mynd 1). Næst er ásgörn (efri hluti mjógirnis) heftuð sundur $60 \mathrm{~cm}$ frá magaportvöðva og fjærhluti ásgarnar hengdur upp og samtengdur við magastúfinn með víðri tengingu. Samgötun tveggja hluta ásgarnar (jejunojejunostomy) er síðan gerð $150 \mathrm{~cm}$ frá samtengingu magastúfs og ásgarnar. Pá hefur myndast hin einkennandi Y-lykkja sem Roux-en-Y aðgerðin er kennd við. Annars vegar hefur rúmmál

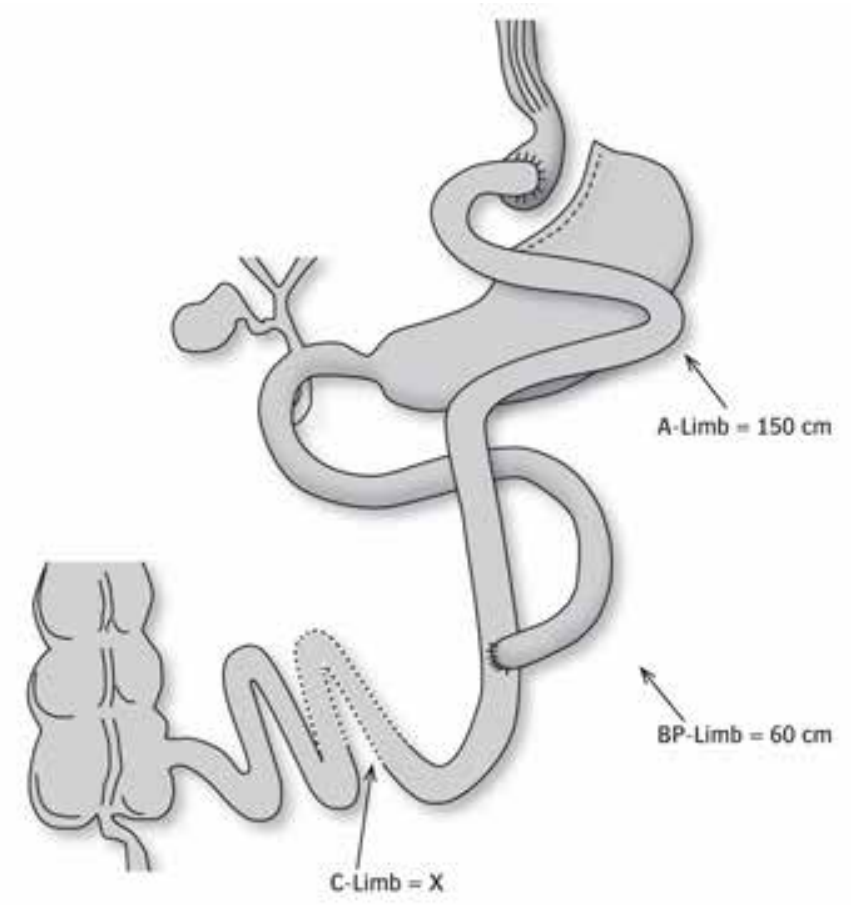

Mynd 1. Skýringarteikning af hjáveituaðgerðá maga.

sem tekur við máltíð minnkað og hins vegar hefur leið matar um meltingarveg verið stytt. Auk pessa kemst matur ekki í snertingu við nærhluta meltingarvegar (foregut) sem veldur breytingu á hormónastarfsemi meltingarvegar. Breytingin leiðir meðal annars til minni áhuga á að matast og mettunartilfinningar við smáar máltíðir. Eftir aðgerðina polir sjúklingurinn mun minna magn fitu og einfaldra kolvetna í máltíðum. Pannig hefur aðgerðin prípætta verkun. Sjúklingurinn polir mun minni máltíðir, polir síður óheppilegar fæðutegundir og loks nýtist næringin síður.

\section{Niðurstöठur}

Frá árinu 2000 voru framkvæmdar 855 aðgerðir vegna sjúklegrar offitu á Landspítala. 83 af aðgerðunum voru enduraðgerðir hjá sjúklingum sem áður höfðu farið í sultarólaraðgerð (magaband, eða vertical banded gastroplasty) og eru pær ekki teknar með í pessa rannsókn.

\section{Rannsóknarpýðið}

Í pessari samantekt er skoðaður árangur 772 sjúklinga sem gengust undir magahjáveituaðgerð með kviðsjá. Meðalaldur við aðgerð var 40,5 ár $( \pm 10,4)$ (spönn 14-73), 83,2\% voru konur, meðalpyngd sjúklinga var 126,6 kg ( $\pm 20,1)$ (spönn 92-225) og meðal BMI $44,0( \pm 5,8)$ (spönn 35-74).

Til undirbúnings fyrir aðgerð fóru 471 sjúklingur (61\%) í atferlismeðferð á Reykjalundi, 113 (15\%) á Kristnesi, 53 (7\%) á Neskaupsstað, 35 (5\%) á göngudeild megrunaraðgerða Landspítala, 31 (4\%) á öðrum meðferðastofnunum en 69 (8\%) úr fyrri hluta tímabilsins fengu engan formlegan undirbúning eða önnuðust undirbúning sjálfir. Á Reykjalundi léttust sjúklingar fyrir aðgerð að meðaltali um $13 \mathrm{~kg}$ (konur $12 \mathrm{~kg}$ og karlar $17 \mathrm{~kg}$ ).

Sjúklingar voru að meðaltali með 2,8 fylgisjúkdóma tengda offitu fyrir aðgerð. Alls 293 sjúklingar (37,6\%) höfðu engan fylgi- 
Tafla I. Fylgisjúkdómar tengdir offitu ( $n=772)$.

\begin{tabular}{|c|c|}
\hline Fylgisjúkdómar & Fjöldi n (\%) \\
\hline Langvinnir liðverkir & $486(63,0)$ \\
\hline Háprýstingur* & $293(38,0)$ \\
\hline Bakverkir & $275(35,6)$ \\
\hline Punglyndi* & $262(33,9)$ \\
\hline Vélindabakflæði* & $165(21,4)$ \\
\hline Kæfisvefn & $145(18,8)$ \\
\hline Skert sykurpol* & $133(17,2)$ \\
\hline Astmi $^{*}$ & $110(14,3)$ \\
\hline Pvagleki (við áreynslu) & $77(10,0)$ \\
\hline Blóðfituraskanir* & $63(8,2)$ \\
\hline Hjarta- og æðasjúkdómur & $48(6,2)$ \\
\hline Fjölblöðrueggjastokkaheilkenni & $40(5,2)$ \\
\hline Enginn fylgisjúkdómur & $293(38,0)$ \\
\hline
\end{tabular}

*Sjúklingar sem eru á meðferð

sjúkdóm. Peir sem voru með fylgisjúkdóm voru pví að meðaltali með 4,5 fylgisjúkdóma (tafla I). 60\% sjúklinga voru með stoðkerfisvandamál (lið- og bakverki); 196 sjúklingar voru á fastri meðferð; 147 tóku verkjalyf, 156 tóku NSAIDs-lyf og 115 tóku lyf úr báðum lyfjaflokkum. $38 \%$ sjúklinga voru á meðferð vegna háprýstings, priðjungur á meðferð vegna punglyndis og $17 \%$ á meðferð vegna sykursýkis af tegund tvö.

Aðgerðartíminn styttist marktækt með tímanum. Á tímabilinu 2002-2005 var meðalaðgerðartíminn 72,6 mínútur $( \pm 15,1)$ samanborið við 32,2 mínútur $( \pm 5,7)$ á tímabilinu 2010-2014 ( $\mathrm{p}<0,001)$.

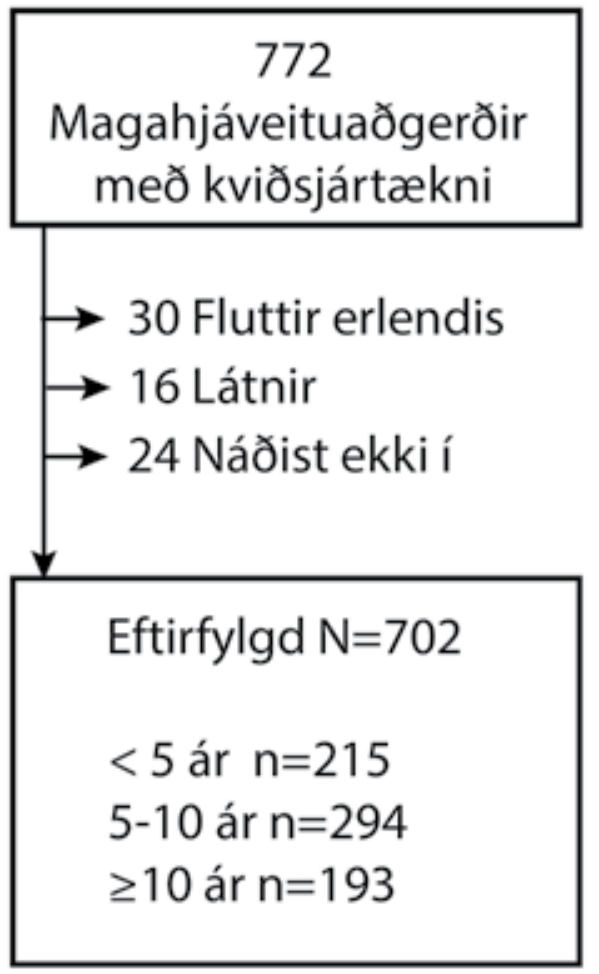

Mynd 2. Flæðirit sem sýnir eftirfylgd.
Tafla II. Snemmkomnir fylgikvillar $(n=772)$.

\begin{tabular}{lcc}
\hline Fylgikvillar ( $\leq 30$ dagar) & Fjöldi $n(\%)$ & Enduraðgerð $\mathrm{n}(\%)$ \\
\hline Blæðing & $19(2,5)$ & $9(1,2)$ \\
\hline Samtengingarleki & $11(1,4)$ & $9(1,2)$ \\
\hline Sárasýking & $2(0,26)$ & $0(0,0)$ \\
\hline Garnastífla & $2(0,26)$ & $2(0,26)$ \\
\hline Lungnavandamál & $2(0,26)$ & $0(0,0)$ \\
\hline Blóðsegarek & $1(0,13)$ & $0(0,0)$ \\
\hline Dánartíðni & $0(0,0)$ & \\
\hline
\end{tabular}

Einungis fylgikvillar sem pörfnuðust virkrar meðferðar eða aðgerðar eru skráðir.

Miðgildi legutíma eftir aðgerð voru tveir dagar (spönn 1-85). Skipulagður legutími voru prír dagar fyrstu prjú árin, tveir dagar næstu 5 árin á eftir en einn dagur frá árinu 2009. Sá sjúklingur sem lengst lá inni eftir aðgerð fékk leka og röð fylgikvilla og lá inni í 85 daga.

Snemmkomnir fylgikvillar $(\leq 30 d)$

4,8\% sjúklinga fengu snemmkomna fylgikvilla (tafla II). Tuttugu sjúklingar (2,6\%) fóru í bráðaaðgerð; 9 vegna leka á magastúf eða mjógirni, 9 vegna blæðingar og tveir vegna garnastíflu.

\section{Eftirfylgni}

30 sjúklingar voru erlendir ríkisborgarar (Bandaríkin, Noregur, Færeyjar) sem hafa ekki verið í eftirliti hérlendis og ekki búsettir á Íslandi. 16 sjúklingar (2\%) voru látnir við lok rannsóknartímabilsins (tafla VII). Prátt fyrir ítrekaðar tilraunir náðist ekki í 24 af 726 sjúklingum vegna rannsóknarinnar. Flestir peirra voru búsettir erlendis. Eftirfylgnin náði pví til 702 af 772 sjúklingum (91\%), sjá flæðirit mynd 2. Meðaltalseftirfylgnitími var 7,4 ár $( \pm 3,5)$ frá aðgerð.

\section{Árangur aðgerðar}

Áhrif á líkamspyngd

Mynd 3a sýnir hlutfallslegt yfirpyngdartap (\%EBMIL) sem er skilgreint sem tap á pyngd umfram BMI $25 \mathrm{~kg} / \mathrm{m}^{2}$. \%EBMIL var að meðaltali $80 \%$ eða $56,9 \mathrm{~kg}( \pm 14,7)$ eftir eitt og hálft ár, 70\% eða 49,6 $\mathrm{kg}( \pm 14,6)$ eftir 5 ár og 64\% eða 48,4 kg $( \pm 14,4)$ eftir 10-13 ár (mynd 3b). Af peim 589 sjúklingum sem fylgt var eftir í meira en prjú ár höfðu 92 sjúklingar (16\%) pyngst tölvert aftur eftir aðgerð og 15 peirra $(2,5 \%)$ sem misstu minna en helming af yfirpyngdinni og töldust með ófullnægjandi pyngdartap (\%EBMIL $\geq 50$ eða BMI>33). Pyngdartap pessa hóps var að meðaltali 39,1\% af yfirpyngd eða 18,2 $\mathrm{kg}( \pm 10,2)$.

\section{Áhrif á fylgisjúkdóma}

Áhrif aðgerðar á fylgisjúkdóma eru sýnd í töflu III. 71,2\% sjúklinga með sykursýki af tegund tvö fyrir aðgerð fóru í fullt sjúkdómshlé eftir aðgerð. 17,2\% sjúklinga fækkuðu föstum lyfjum um meira en helming. 11,3\% eru á óbreyttri lyfjameðferð eða á fleiri lyfjum. Einn sjúklingur greindist með sykursýki sem ekki var til staðar fyrir aðgerð. Sá hafði náð góðum árangri og haldið fyrstu fjögur árin en síðan pyngst um $21 \mathrm{~kg}$ á 5 árum úr $25 \mathrm{~kg} / \mathrm{m}^{2}$ í $34 \mathrm{~kg} / \mathrm{m}^{2}$. 


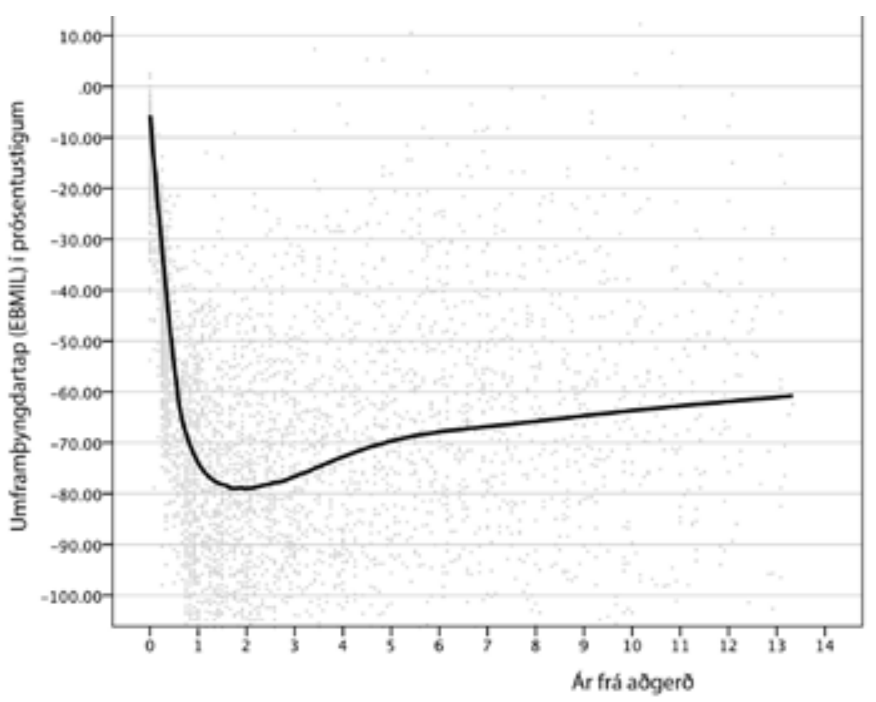

Mynd 3a. Pyngdartap eftir magahjáveituaðgerð uppgefið sem hlutfallslegt tap af yfirbyngd (\%EBMIL), sýnt ár eftir aðgerð. Við 100\% EBMIL er líkamsstuðli 25 náð. Notuð er tölfræðiaðferðin locally weighted scatter plot smoothing method (lowess).

Tafla III. Áhrif aðgerðar á fylgisjúkdóma eftir 2-14 ár (n=702).

\begin{tabular}{lccccc}
\hline Fylgisjúkdómur & $\begin{array}{c}\text { Fjöldi } \\
\mathrm{n}(\%)\end{array}$ & $\begin{array}{c}\text { Verri } \\
\mathrm{n}(\%)\end{array}$ & $\begin{array}{c}\text { Óbreyttur } \\
\mathrm{n}(\%)\end{array}$ & $\begin{array}{c}\text { Betri } \\
\mathrm{n}(\%)^{\star}\end{array}$ & $\begin{array}{c}\text { Fullur bati } \\
\mathrm{n}(\%)^{\star \star}\end{array}$ \\
\hline Sykursýki-2 & $80(11,4)$ & $1(1,3)$ & $8(10,0)$ & $14(17,5)$ & $57(71,2)$ \\
\hline Háprýstingur & $\begin{array}{c}212 \\
(30,2)\end{array}$ & $5(2,4)$ & $55(25,9)$ & $78(36,8)$ & $74(34,9)$ \\
\hline Blóðfituraskanir & $55(7,8)$ & $3(5,5)$ & $7(12,7)$ & $24(43,6)$ & $21(38,2)$ \\
\hline Kæfisvefn & $\begin{array}{c}138 \\
(19,7)\end{array}$ & $2(1,4)$ & $15(10,9)$ & $44(31,9)$ & $77(55,8)$ \\
\hline $\begin{array}{l}\text { Lið- og } \\
\text { bakverkir }\end{array}$ & $\begin{array}{c}460 \\
(65,5)\end{array}$ & $84(18,3)$ & $\begin{array}{c}131 \\
(28,4)\end{array}$ & $\begin{array}{c}195 \\
(42,4)\end{array}$ & $50(10,9)$ \\
\hline
\end{tabular}

* Skilgreint sem inntaka á helmingi færri mismunandi lyfjum

${ }^{*}$ Skilgreint sem inntaka á engum lyfjum

Priðjungur sjúklinga á háprýstingsmeðferð fyrir aðgerð var án blóðprýstingslyfja við síðustu eftirfylgd. Priðjungur hefur minnkað lyfjatöku. Priðjungur var á óbreyttri eða aukinni lyfjameðferð. Einn sjúklingur greindist með háprýsting sem ekki var til staðar fyrir aðgerð. $8 \%$ sjúklinga voru á meðferð vegna blóðfituraskana, en flestir fengu verulega bót af aðgerðinni (tafla III). Enginn sjúklingur greindist með nýtilkomna blóðfituröskun eftir aðgerð. Alls voru 138 sjúklingar (20\%) með kæfisvefn fyrir aðgerð og 87 sjúklingar (63\%) notuðu ytri öndunarvél (CPAP). Við síðustu eftirfylgd notaði 21 sjúklingur (24\%) áfram ytri öndunarvél en 66 sjúklingar (76\%) höfðu losnað við vélina. 121 sjúklingur (87,7\%) fékk bót eða fullan bata af kæfisvefni. Tveir sjúklingar (0,3\%) greindust með kæfisvefn sem var ekki til staðar fyrir aðgerð, báðir nota ytri öndunarvél. Rúmlega helmingur sjúklinga (53\%) með lið- og bakverki voru betri eða fengu fulla bót á einkennum sínum eftir aðgerð.

Síðkomnir fylgikvillar (>30d eftir aðgerð)

174 sjúklingar (25\%) fengu síðkomna fylgikvilla (tafla IV). 78 (11\%) sjúklingar með einkenni sem gátu bent til garnaklemmu í

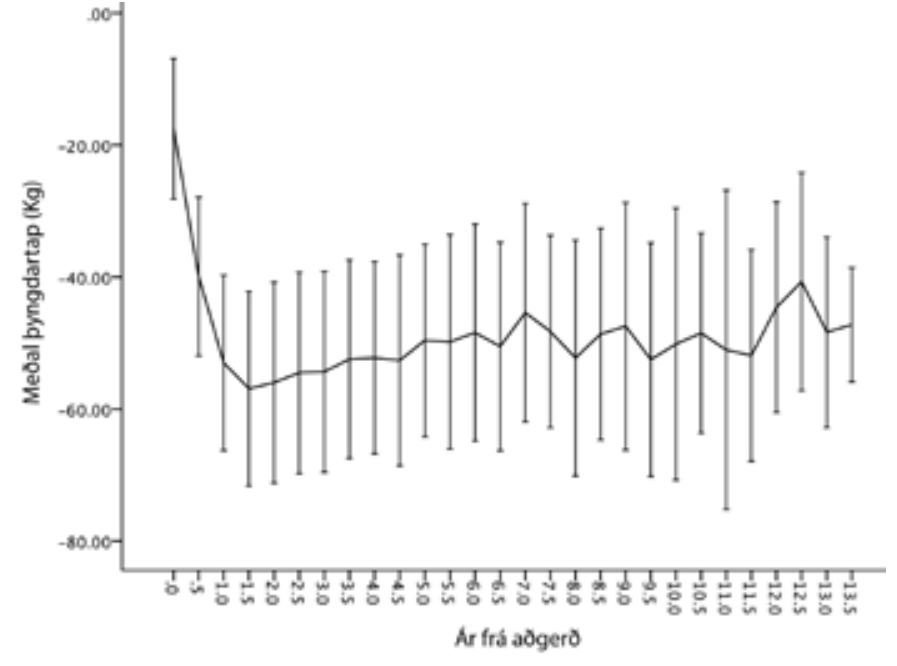

Mynd 3b. Pyngdartap eftir hjáveituaðgerð gefið upp í kílóum með staðalfráviki (kg $\pm 1 S D$ ).

Tafla IV. Síckomnir fylgikvillar $(n=702)$.

\begin{tabular}{lcc}
\hline Fylgikvillar (> 30 dagar) & Fjöldi n (\%) & Aðgerð vegna fylgikvilla $\mathrm{n}(\%)$ \\
\hline Sár í magastúf & $63(9,0)$ & $27(4)$ \\
\hline Óútskýrðir kviðverkir & $52(7,4)$ & $52(7,4)$ \\
\hline Innhaull í garnaglufu & $46(6,6)$ & $46(6,6)$ \\
\hline Innhaull í kviðvegg & $9(1,3)$ & $9(1,3)$ \\
\hline Alvarleg næringarvandamál & $4(0,6)$ & $4(0,6)$ \\
\hline
\end{tabular}

Einungis fylgikvillar sem pörfnuðust virkrar meðferðar eða að̆gerðar eru skráđir.

garnaglufu (internal hernia) fóru í kviðsjáraðgerð og reyndust 46 peirra $(6,6 \%)$ vera með garnaklemmu (tafla IV).

Hjá 5 sjúklingum var um alvarlega garnaklemmu að ræða og purfti að fjarlægja hluta af mjógirni. 63 sjúklingar (9\%) greindust með magasár og pörfnuðust 27 peirra (4\%) úrlausnar með aðgerð. Fimmtán peirra voru með sár sem greri ekki með lyfjameðferð. Fimm voru með sár sem ollu prengingu á samtengingu magastúfs og mjógirnis sem krafðist enduraðgerðar með nýrri samtengingu. Sjö sjúklingar fóru í bráðaaðgerð vegna rofs á sári í magastúf, frátengda maganum eða skeifugörn. Tíðni magasára minnkaði marktækt úr $24 \%$ sjúklinga á fyrsta priðjungi í 3\% á síðasta priðjungi rannsóknartímabilsins.

Pess má geta að 34 sjúklingar (5\%) fóru í gallblöðrutöku eftir hjáveituaðgerðina, en gallsteinasjúkdómur telst pó ekki vera fylgikvilli aðgerðar. Um 78\% sjúklinga purftu að gera breytingar á inntöku vítamína og bætiefna eftir niðurstöður blóðprufa í eftirliti, oft mörgum árum eftir aðgerð. Fjórir sjúklingar (0,6\%) fengu alvarleg næringarvandamál (tveir með lifrarbilunareinkenni og tveir með alvarlegan próteinskort) og purftu á sjúkrahúsinnlögnum að halda.

\section{Óprgindi eftir aðgerð}

Helstu ópægindi sem sjúklingar lýsa eftir aðgerð má sjá í töflu V. Ekki var skoðað hve mikil eða alvarleg pessi ópægindi eru. 
Tafla V. Ópægindi eftir aðgerð ( $n=702)$.

\begin{tabular}{lc}
\hline Ópægindi & Fjöldi, $\mathrm{n}(\%)$ \\
\hline Kviðverkir & $115(16,4)$ \\
\hline Preyta & $110(15,7)$ \\
\hline Niðurgangur (linar hægðir) & $69(9,8)$ \\
\hline Erfiðleikar við að borða & $62(8,8)$ \\
\hline Garnagaul & $56(8,0)$ \\
\hline Hægðatregða & $38(5,4)$ \\
\hline Engin ópægindi & $303(43,2)$ \\
\hline
\end{tabular}

Rúmlega helmingur sjúklinga lýsti að minnsta kosti einni gerð ópæginda.

\section{Meðferðarheldni}

Langflestir sjúklinganna $(77,6 \%)$ tóku vítamín daglega og fylgdu ráðleggingum meðferðarteymisins á Landspítala (tafla VI). Aðeins 11,4\% tóku vítamín sjaldan eða aldrei. $81,5 \%$ sjúklinga kváðust fara reglulega í blóðprufueftirlit en 18,5\% sjaldan eða aldrei. $63 \%$ stunduðu líkamsrækt sjaldan eða aldrei, en 37\% oft eða daglega. Tafla VI sýnir að 33,8\% reyktu fyrir aðgerð. Helmingur peirra hætti reykingum eftir aðgerð. Fimmtán sjúklingar (3\%) sem reyktu ekki fyrir hófu reykingar eftir aðgerð.

Lifun

Alls eru 16 af 772 (2\%) látnir eftir aðgerð. Í töflu VII er greint frá dánarorsökum og tímalengd frá aðgerð.

\section{Umræður}

Mörgum mismunandi skurðaðgerðum hefur verið beitt frá árinu 1960 til hjálpar sjúklingum með sjúklega offitu. Fæstar hafa staðist tímans tönn. Árið 1967 hófust hjáveituaðgerðir á maga og eru pær enn taldar álitlegasti kosturinn með tilliti til ávinnings og áhættu aðgerðar. ${ }^{26,27}$ Aðgerðirnar voru áður gerðar með kviðarholsskurði en peim opnu aðgerðum fylgdi töluverð hætta á fylgikvillum, svo sem kviðsliti, lungnabólgu, blóðtappa og fleiru. Tilkoma nýrrar aðgerðartækni hefur auðveldað aðgerðirnar og gert pær viðaminni og öruggari. ${ }^{28-30}$ Fyrstu hjáveituaðgerðir með kviðsjá voru gerðar 1994 en pær urðu ekki vinsæll kostur fyrr en eftir aldamótin. ${ }^{31}$

Tafla VII. Andlát eftir aðgerð $(n=16)$.

\begin{tabular}{lcc}
\hline Dánarorsök & Fjöldi, $\mathrm{n}(\%)$ & Tími frá ađgerð \\
\hline Krabbamein & $6(37,5)$ & $4,6,6,9,9,9$ ár \\
\hline Sjálfsvíg & $3(18,8)$ & 4 mánuðir, 2,5 ár \\
\hline Hjartasjúkdómur & $2(12,5)$ & 2,9 ár \\
\hline Sýkingar & $2(12,5)$ & 6,9 ár \\
\hline Slysfarir & $1(6,3)$ & 8 ár \\
\hline Morð & $1(6,3)$ & 7 ár \\
\hline Ópekkt orsök & $1(6,3)$ & 9 ár \\
\hline
\end{tabular}

Tafla VI. Meðferðarheldni.

\begin{tabular}{lcccc} 
Lífsstíll & Aldrei & Sjaldan & Oft & Daglega \\
\hline Inntaka bætiefna $(\mathrm{n}=695)$ & $32(4,6)$ & $47(6,8)$ & $71(10,2)$ & $545(78,4)$ \\
\hline Líkamsrækt $(\mathrm{n}=701)$ & $206(29,4)$ & $233(33,2)$ & $206(29,4)$ & $56(8,0)$ \\
Blóðprufueftirlit $(\mathrm{n}=692)$ & Aldrei/sjaldan & Reglulega \\
\hline Reykingar (698) & $128(18,5)$ & $564(81,5)$ \\
\hline \multicolumn{1}{c}{ Fyrir aðgerð } & Nei & Já \\
\hline Eftir aðgerð & $463(66,3)$ & $235(33,7)$ \\
\hline
\end{tabular}

Pegar hjáveituaðgerðir með kviðsjártækni hófust á Landspítala í byrjun árs 2001 var pað með fyrstu sjúkrahúsum Evrópu til að framkvæma slíkar aðgerðir. Síðan pá hefur aðgerðartæknin verið í stöðugri frampróun og bæði legutími og tíðni fylgikvilla minnkað verulega.

\section{Sjúklingapýdið og árangur}

Sjúklega of feitir eru í áhættuhópi til skurðaðgerðar. Annars vegar vegna áhrifa offitu á aðkomu í kvið og að öndunarvegi og hins vegar vegna alvarlegra fylgisjúkdóma offitu. Einnig er aukin hætta á blóðtöppum hjá of feitum. Sérstakan gaum ber að gefa efnaskiptaheilkenni (metabolic syndrome) sem felur í sér verulegan heilsubrest, aukna áhættu hjarta- og æðasjúkdóma og skerta ævilengd. ${ }^{32-36}$ Til að meta, undirbúa og fræða sjúklinga um eðli og áhættu aðgerðar fóru flestir sjúklingar í formeðferð á meðferðarstofnunum sem offituteymi Landspítala er í samvinnu við. Par léttust sjúklingar að meðaltali um $9 \mathrm{~kg}$ og við pað verður aðkoman í kviðarholinu auðveldari vegna minni lifrarfitu og aðgerðin verður öruggari fyrir vikið.

Tap á yfirpyngd einu og hálfu ári eftir aðgerð var að meðaltali $80 \%$. Eftir pað pyngdist meirihluti sjúklinga nokkuð aftur og 10-14 árum eftir aðgerð var yfirpyngd að meðaltali 65\% minni en fyrir aðgerð (mynd 3a). Ferill pyngdartapsins er sambærilegur pví sem pekktar meðferðarstofnanir í fremstu röð erlendis hafa sýnt. ${ }^{37}$ 84,8\% sjúklinga náðu fullnægjandi pyngdartapi með meðaleftirfylgnitíma 7,4 ár eftir aðgerð.

Tíðni offitutengdra fylgisjúkdóma er verulega aukin hjá sjúklingum með sjúklega offitu. ${ }^{38}$ Í pessari rannsókn er tíðni offitutengdra fylgisjúkdóma svipuð og stórar erlendar samantektarrannsóknir hafa sýnt. ${ }^{17}$

Rannsóknin sýnir að stór hluti fylgisjúkdóma offitu batnar eða fer í sjúkdómshlé. Sérstaklega varð mikil bót á sykursýki af tegund tvö, háprýstingi og blóðfituröskunum líkt og erlendar rannsóknir hafa sýnt. ${ }^{32-36}$ Mjög erfitt er að meðhöndla sykursýki af tegund tvö fullnægjandi hjá sjúklingum með sjúklega offitu sem leiðir til aukins sjúkleika og minnkaðra lífslíkna. ${ }^{39,40}$ Prátt fyrir að hluti sjúklinga fái sjúkdóminn aftur með tímanum má líta svo á að ár eða áratugir án sykursýki sé verulegur ávinningur. Eliasson og meðhöfundar ${ }^{20}$ birtu nýverið grein í Lancet sem sýnir lækkaða dánartíðni hjá sjúklingum með sykursýki af tegund tvö sem farið höfðu í offituaðgerð. Einnig sýndu peir lækkaða dánartíðni af völdum hjarta- og æðasjúkdóma í pessum sjúklingahópi. 
Stór hluti sjúklinga með kæfisvefn varð einkennalaus eftir aðgerð. Auk pess voru áhrif á lið- og bakverki umtalsverð. Fjölmargar rannsóknir hafa sýnt fram á að fjöldi sjúklinga með pessa sjúkdóma fá bót eftir aðgerð. 17,41,42 Líta má svo á að magahjáveituaðgerð seinki ýmsum lífsstílstengdum sjúkdómum um mörg ár með tilheyrandi aukningu á lífsgæðum.

\section{Fylgikvillar og vandamál eftir aðgerð}

Snemmkomnir fylgikvillar ( $\leq 30 \mathrm{~d}$ ) greindust hjá 4,8\% sjúklinga sem er svipuð tíðni og hjá erlendum meðferðarstofnunum. ${ }^{32-36} \mathrm{Al}-$ gengustu snemmkomnu fylgikvillarnir voru blæðingar $(1,2 \%)$ og leki á samtengingum (1,2\%). Pessir fylgikvillar eru vel viðráðanlegir ef snemma er gripið inn i.43-44

Fjórðungur sjúklinga (174) fengu síðkomna fylgikvilla (>30d) eftir aðgerð. Sérstaklega var há tíðni síðkominna fylgikvilla á fyrri hluta rannsóknartímabilsins, sem var áhyggjuefni. Með tímanum hefur bætt aðgerðartækni og aukin reynsla skurðlækna væntanlega lækkað tíðni pessara fylgikvilla. Í heildina fengu 9\% sjúklinga magasár. Breytt aðgerðartækni með minni magastúf og breyttu horni á samtengingu garnar við magastúf hefur lækkað tíðni magasára eftir aðgerð. Nú er tíðnin um 3\% og alvarleg magasár sjaldgæf nú til dags. ${ }^{45}$

Fyrir árið 2010 var garnaglufum ekki lokað. Pá var tíðni innhauls hærri en ásættanlegt er, eða um 10\%. Aðgerðarteymi tveggja meðhöfunda pessarar greinar (HGG, BGL) próuðu í Svípjóð og Noregi nýja aðferð til að loka garnaglufum. ${ }^{46}$ Sú aðferð, sem tekin var í notkun hér á landi í ársbyrjun 2011, lækkar tíðni pessa fylgikvilla niður í 1-2\%. ${ }^{47}$ Pessi aðferð er nú notuð af mörgum skurðlæknum sem gera magahjáveituaðgerðir í Evrópu.

Í pessari rannsókn minnkaði tíðni fylgikvilla verulega á rannsóknartímabilinu, ef fyrsti priðjungur er borinn saman við síðasta priðjung (tíðni magasára og innhauls). Við gerum ráð fyrir að aukin reynsla meðferðarteymis og breytt aðgerðartækni skipti mestu máli í pessu samhengi.

Algengasti síðkomni fylgikvillinn var vítamín- og steinefnaskortur. Skorturinn er yfirleitt vægur en mikilvægt er að hafa reglulegt eftirlit með blóðprufum. Komið er í veg fyrir pennan skort með markvissri fæðubótarinntöku. ${ }^{48}$ Hjá allflestum sjúklinganna (78\%) purfti iðulega að gera breytingar á skammtastærðum bætiefna í samræmi við niðurstöður úr blóðprufum, oft mörgum árum eftir aðgerð. Petta sýnir nauðsyn pess að sjúklingar séu í reglulegu eftirliti og taki bætiefni. Fjöldi sjúklinga með alvarlegan næringarskort eftir aðgerð er pví mælikvarði á gæði eftirlits og meðferðarheldni sjúklings.

Geðræn vandamál eru algeng meðal sjúklinga sem pjást af sjúklegri offitu. ${ }^{49,50}$ Um priðjungur sjúklinga var á punglyndismeðferð fyrir aðgerð. Ljóst er að punglyndi og aukaverkanir punglyndislyfja geta stuðlað að offitu. Einnig getur offita verið orsakapáttur punglyndis og leitt til félagslegrar einangrunar. ${ }^{48,49}$ Prír sjúklingar $(0,4 \%)$ frömdu sjálfsvíg eftir aðgerð. Pekkt er að tíðni sjálfsvígstilrauna og sjálfsvíga er tölvert aukin meðal einstaklinga með alvarlega offitu. ${ }^{51,52}$ Einnig hefur verið sýnt fram á aukna tíðni sjálfsvíga meðal einstaklinga sem hafa farið í offituaðgerð. ${ }^{53}$ Okkar prír sjúklingar höfðu allir lést ágætlega eftir aðgerð og ekki haft fylgikvilla, en einn var í alvarlegri áfengisneyslu, annar í áfengisog lyfjaneyslu, en sá priðji hafði enga pekkta áhættupætti.

Offituaðgerðir eru með algengustu kviðarholsaðgerðum á Vesturlöndum nú til dags ${ }^{53}$ Magahjáveituaðgerð hefur verið algengust peirra síðustu áratugi. Nú er önnur aðgerð, magaermi (gastric sleeve), í vaxandi mæli að ryðja sér til rúms sem eftirsótt aðgerð. Segja má að sú aðgerð sé mildari en magahjáveituaðgerð en pyngdartap til langframa er minna. Jafnframt eru fylgikvillar og næringarvandamál eftir aðgerð töluvert vægari. ${ }^{26,55}$ Magaermi er nú til dags algengasta aðgerðin hjá sjúklingum með vægara stig offitu, hjá ungum konum, sjúklingum með andleg vandamál og sjúklingum par sem búast má við slakri meðferðarheldni.

\section{Lifsstílsbreytingar eftir aðgerð}

Pegar kviðsjáraðgerðirnar hófust varð til sérstakt meðferðarteymi offitu á Landspítala sem samanstendur af læknum, hjúkrunarfræðingum og næringarfræðingi. Lögð er rík áhersla á pað við sjúklinga að aðgerðin sé aðeins hjálpartæki og umfangsmikil lífsháttabreyting sé nauðsynleg til að góður langtímaárangur náist.

Meltingarfæraópægindi eru vel pekkt aukaverkun magahjáveituaðgerðar. Ópægindi pessi haldast oft í hendur við hversu vel sjúklingi tekst að gera nauðsynlegar breytingar á matarvenjum sínum. Eftir aðgerð purfa sjúklingar að temja sér að borða hægt og margar litlar máltíðir ásamt pví að sneiða hjá einföldum kolvetnum og mikilli fitu. Hins vegar eru meltingarfæraópægindi algeng hjá sjúklingum með sjúklega offitu. ${ }^{56}$ Ópægindin minnka gjarnan eftir aðgerð en eru pó meiri en hjá einstaklingum í eðlilegum holdum.

\section{Lokaniðurstaða}

Magahjáveituaðgerð hefur í för með sér mikið og varanlegt pyngdartap hjá meirihluta sjúklinga. Aðgerðin veldur umtalsverðum bata á flestum fylgisjúkdómum offitu og eru áhrifin á sykursýki af tegund tvö, háprýsting og blóðfituraskanir veruleg. Pegar sjúklingar með sjúklega offitu fá slíka sjúkdóma ber að íhuga aðgerð sem meðferðarúrræði. ${ }^{57}$ Sjúkleg offita er sjúkdómur sem flestir sjúklinganna losna við eftir aðgerð en hluti sjúklinga fær fylgikvilla sem getur purft að leysa með nýrri aðgerð. Аð gangast undir magahjáveituaðgerð er mikil skuldbinding sem krefst góðrar meðferðarheldni og ævilangt eftirlit er nauðsynlegt til að hindra næringarvandamál síðar.

\section{Pakkir}

Sérstakar pakkir fá Svava Engilbertsdóttir næringarráðgjafi og hjúkrunarfræðingarnir Sigrún Árnadóttir, Jarprúður Jónsdóttir og Kristín Rún Friðriksdóttir sem hafa frá upphafi sinnt sjúklingum offituaðgerða af mikilli alúð og fagmennsku á göngudeild megrunaraðgerða Landspítala. Ennfremur pökkum við samstarfsaðilum okkar, sérstaklega á Reykjalundi og Kristnesi, sem annast hafa formeðferð og undirbúning sjúklinga fyrir aðgerð. 


\section{Heimildir}

1. Obesity: preventing and managing the global epidemic Report of a WHO consultation World Health Organization technical report series. 2000; 894: i-xii, 1-253.

2. Finucane MM, Stevens GA, Cowan MJ, Danaei G, Lin JK, Paciorek CJ, et al. National, regional, and global trends in body-mass index since 1980: systematic analysis of health examination surveys and epidemiological studies with 960 country-years and 9.1 million participants. Lancet 2011; 377: 557-67.

3. Pórsson B, Aspelund T, Harris TB, Launer LJ, Guðnason V. próun holdafars og sykursýki i 40 á Íslandi. Læknablaðið 2009; 95: 259-66.

4. Alberti KG, Eckel RH, Grundy SM, Zimmet PZ, Cleeman JI, Donato KA, et al. Harmonizing the metabolic syndrome: a joint interim statement of the International Diabetes Federation Task Force on Epidemiology and Prevention; National Heart, Lung, and Blood Institute; American Heart Association; World Heart Federation; International Atherosclerosis Society; and International Association for the Study of Obesity. Circulation 2009; 120: $1640-5$

5. Alberti KG, Zimmet P, Shaw J, Grundy SM. The metabolic syndrome--a new worldwide definition. Lancet 2005; 366: 1059-62.

6. Sundstrom J, Riserus U, Byberg L, Zethelius B, Lithell $\mathrm{H}$ Lind L. Clinical value of the metabolic syndrome for long term prediction of total and cardiovascular mortality: prospective, population based cohort study. BMJ 2006; 332: 878-82.

7. Batsis JA, Romero-Corral A, Collazo-Clavell ML, Sarr MG Somers VK, Lopez-Jimenes F. Effect of bariatric surgery on the metabolic syndrome: a population-based, long-term controlled study. Mayo Clin Proc 2008; 83: 897-907.

8. Calle EE, Thun MJ, Petrelli JM, Rodriguez C, Heath CW, Jr. Body-mass index and mortality in a prospective cohort of U.S. adults. N Engl J M 1999; 341: 1097-105.

9. Zoppini G, Verlato G, Leuzinger C, Zamboni C, Brun E, Bonora $\mathrm{E}$, et al. Body mass index and the risk of mortality in type II diabetic patients from Verona. Int J Obes Relat Metab Disord 2003; 27: 281-5.

10. Bianchini F, Kaaks R, Vainio H. Overweight, obesity, and cancer risk. Lancet Oncology 2002; 3: 565-74.
11. Avenell A, Brown TJ, McGee MA, Campbell MK, Grant $\mathrm{AM}$, Broom J, et al. What are the long-term benefits of weight reducing diets in adults? A systematic review of randomized controlled trials. J Hum Nutr Diet 2004; 17 317-35.

12. Avenell A, Brown TJ, McGee MA, Campbell MK, Gran AM, Broom J, et al. What interventions should we add to weight reducing diets in adults with obesity? A systematic review of randomized controlled trials of adding drug therapy, exercise, behaviour therapy or combinations of these interventions. J Hum Nutr Diet 2004; 17: 293-316.

13. Dansinger ML, Gleason JA, Griffith JL, Selker HP, Schaefer EJ. Comparison of the Atkins, Ornish, Weight Watchers, and Zone diets for weight loss and heart disease risk reduction: a randomized trial. JAMA 2005; 293: 43-53.

14. Bravata DM, Sanders L, Huang J, Krumholz HM, Olkin I, Gardner CD, et al. Efficacy and safety of low carbohydrate diets: a systemic review. JAMA 2003; 289: 1837-50.

15. Yanovski SZ, Yanovski JA. Long-term drug treatment for obesity. A systematic and clinical review. JAMA 2014; 311: 74-86.

16. Svetkey LP, Stevens VJ, Brantley PL, Apple LJ, Hollis JF, Loria CM, et al. Comparison of strategies for sustaining weight loss: the weight loss maintenance randomized controlled trial JAMA 2008: 299: 1139-48.

17. Buchwald $\mathrm{H}$, Avidor $\mathrm{Y}$, Braunwald E, Jensen MD, Pories W, Fahrbach K, Schoelles K, et al. Bariatric surgery: a systematic review and meta-analysis. JAMA 2004 13; 292: 1724-37.

18. Adams TD, Gress RE, Smith SC, Halversen RC, Simper SC, Rosamond WD, et al. Long-term mortality after gastric bypass surgery. N Engl J Med 2007; 357: 753-61.

19. Christou NV, Sampalis JS, Liberman M, Look D, Auger S, McLean AP, et al. Surgery decreases long-term mortality, morbidity, and health care use in morbidly obese patients. Ann Surg 2004; 240: 416-23; discussion 23-4.

20. Eliasson B, Liakopoulos V, Franzén S, Näslund I, Svensson AM, Ottoson J, Gudbjörnsdóttir S. Cardiovascular disease and mortality in patients with type 2 diabetes after bariatric surgery in Sweden: a nationwide, matched, observational cohort study. Lancet Diab Endocrinol 2015; 3: $847-54$
21. Fried M, Yumuk V, Oppert JM, Scopinaro N, Torres A, Weiner $\mathrm{R}$, et al. Interdisciplinary European guidelines on metabolic and bariatric surgery. Obesity Surg 2014; 24: 42-55.

22. Buse JB, Caprio S, Cefalu WT, Ceriello A, Del Prato S, Inzucchi SE, Et al. How do we define cure of diabetes? Diab Care 2009; 32: 2133-5.

23. Birgisson G, Guðmundsson L. Offitumeðferð á Reykjalundi. Sjúkrapjálfarinn 2005; 32: 22-4.

24. Hannesdóttir SH, Guðmundsson ÁL, Jóhannsson E. Heilsufarslegar breytingar sjúklinga í atferlismiðaðri offitumeðferð. Læknablaðið 2011; 97: 597-602.

25. Olbers $T$, Lönroth $H$, Fagevik-Olsen $M$, Lundel L. Laparoscopic gastric bypass: development of technique, respiratory function, and long-term outcome. Obes Surg 2003; 13: 364-370.

26. Carlin AM, Zeni TM, English WJ, Hawasli AA, Genaw JA, Krause KR, et al. The comparative effectiveness of sleeve gastrectomy, gastric bypass, and adjustable gastric banding procedures for the treatment of morbid obesity. Ann Surg 2013; 257: 791-7.

27. Sovik TT, Taha O, Aasheim ET, Engstrom M, Kristinsson J, Bjorkman S, et al. Randomized clinical trial of laparoscopic gastric bypass versus laparoscopic duodenal switch for superobesity. Br J Surg 2010; 97: 160-6.

28. Lujan JA, Frutos MD, Hernandez Q, Liron R, Cuenca JR, Valero $G$, et al. Laparoscopic versus open gastric bypass in the treatment of morbid obesity: a randomized prospective study. Ann Surg 2004; 239: 433-7.

29. Nguyen NT, Goldman CD, Ho HS, Gosselin RC, Singh A, Wolfe BM. Systemic stress response after laparoscopic and open gastric bypass. J Am Coll Surg 2002; 194: 557-66.

30. Westling A, Gustavsson S. Laparoscopic vs open Rouxen-Y gastric bypass: a prospective, randomized trial. Obes Surg 2001; 11: 284-92.

Heimildir 31-57 eru birtar á heimasíðu blaðsins.

\section{ENGLISH SUMMARY}

\section{Outcome of gastric bypass surgery in Iceland 2001-2015}

Rósamunda Pórarinsdóttir¹, Vilhjálmur Pálmason', Björn Geir Leifsson², Hjörtur Gíslason²

Introduction: Laparoscopic roux-en-y gastric bypass (LRYGB) has been performed at Landspitali University Hospital (LSH) since 2001. The procedure represents an important treatment option for morbidly obese patients. The aim of this study is to evaluate the long-term results of these operations in Iceland.

Material and methods: All 772 consecutive patients undergoing LRYGB at LSH during 2001-2015 were included. Information was collected from a prospective database. Successful weight loss was defined as body mass index (BMI) less than $33 \mathrm{~kg} / \mathrm{m}^{2}$ or excess body mass index loss (EBMIL) more than 50\%.

Results: Mean age of patients was 41 years and $83 \%$ were females. Mean pre-operative weight was $127 \mathrm{~kg}( \pm 20)$ and mean BMI was 44 $( \pm 6)$. Mean $\%$ EBMIL was $80 \%$ after 1.5 year, $70 \%$ after 5 years and $64 \%$ after $10-13$ years. $85 \%$ of patients had successful weight loss with a mean follow-up time of 7.4 years. Pre-operatively patients on average had 2.8 obesity related comorbid diseases. $71 \%$ of patients with type 2 diabetes were in full remission after surgery. One third of patients with hypertension and one third of patients with hyperlipidemia achieved full remission after surgery. 37 patients $(5 \%)$ had an early complication and $174(25 \%)$ had a late complication that frequently needed surgical solution. Most patients (78\%) needed repeated adjustment of vitamins and minerals often many years after surgery.

Conclusion: Majority of patients achieved a successful weight loss and most obesity related comorbidities are still in remission 7.4 years after surgery. Early complications were rare but one fourth of patients had late complications. Life long follow-up is of utmost importance after gastric bypass surgery.

${ }^{1}$ Department of Medicine, University of Iceland, ${ }^{2}$ Surgical department Landspitali University Hospital.

Key words: gastric bypass surgery in Iceland 2001-2015.

Correspondence: Hjörtur Gíslason, hjorturg@landspitali.is 